\title{
ABSTRAK \\ PERBANDINGAN HASIL BELAJAR SISWA MELALUI PEMBELAJARAN INKUIRI ANTARA METODE TANYA JAWAB DENGAN KERJA KELOMPOK
}

\author{
Surati, Dosen Program Studi Pendidikan Biologi, \\ Fakultas Ilmu Tarbiyah dan Keguruan, IAIN Ambon, \\ 081231226671, email: iaintarbiyah1970@ gmail.com
}

\begin{abstract}
Hasil belajar antara siswa yang diajarkan dengan pembelajaran inkuiri metode tanya jawab dan metode kerja kelompok menunjukkan tidak ada perbedaan yang signifikan. Berdasarkan hasil hasil uji t dimana thitung sebesar 0,56 lebih kecil dari tabel 2,069 yang berarti tidak ada pengaruh yang signifikan pada hasil belajar antara metode tanya jawab dan kerja kelompok terhadapahasil belajar siswa
\end{abstract}

kata kunci: inquary, kerja kelompok, tanya jawab

\section{ABSTRACT \\ A COMPARISON OF STUDENT LEARNING OUTCOMES THROUGH LEARNING INKUIRI BETWEEN QUESTION AND ANSWER METHOD WITH GROUP WORK}

Learning between the students who are taught by learning inkuiri method question and answering integration and method of work group indicated no difference significant. Based on the test results $t$ calculate is 0,56 smaller than t table is 2,069 that means no significant influence on the study between method of integration and employment without group of students learning

keywords: inquary, working groups, question and answer

Prestasi akademik seorang akademiknya sangat dipengaruhi oleh pebelajar dipengaruhi oleh kemampuan keterampilan berpikir yang dapat dilatih berpikir yang dapat dilatih dan dan dikembangkan di sekolah, dimana dikembangkan melalui proses akademik keterampilan berpikir merupakan salah baik di lembaga formal maupun non satu kecakapan hidup yang sangat penting formal. Bagi seorang siswa prestasi yang harus dimiliki oleh seorang siswa 
untuk modal hidupnya kelak apabila terjun ke masyarakat dan siap menghadapi tuntutan abad 21, SDM yang berkualitas tinggi yang memiliki kecakapan berpikir tinggi. Salah satu skecakapan hidup (life skill) yang perlu dikembangkan melalui proses pendidikan adalah keterampilan berpikir. Hal ini menunjukkan bahwa pengetahuan dapat diperoleh dengan kemampuan berpikir, terutama dalam upaya memecahkan masalah dalam kehidupan sehari-hari (Usman, 1994).

Menurut Corebima dan Idrus (2005), bahwa upaya pengembangan potensi berpikir siswa belum diupayakan secara terencana dan terintegrasi dalam pembelajaran IPA. Demikian pula berdasarkan pengamatan di sekolahsekolah, dalam proses pembelajaran di kelas, guru lebih menekankan pada pemahaman konsep dan mengingat kembali pelajaran yang telah disampaikan dan pencarian satu jawaban yang benar terhadap soal-soal yang diberikan dan belum mengupayakan keterampilan berpikir tingkat tinggi. Proses-proses pemikiran tingkat tinggi jarang sekali dilatihkan.
Piaget menyatakan ada empat periode utama dalam perkembangan kemampuan berpikir dan berkorelasi dengan usia yaitu: periode sensorimotor (usia 0 - 2 tahun), periode praoperasional (usia 2 - 7 tahun), periode oparasional kongkrit (usia 7 - 11 tahun), dan periode operasional formal (usia 11 sampai dewasa). Selanjutnya menunjukkan bahwa anak-anak yang belajar di sekolah untuk pertama kali adalah bersifat "praoperasional", atau didominasi oleh persepsi-persepsinya. Pada usia sepuluh tahun pertama, sebagian besar siswa mengembangkan kemampuannnya untuk menjalankan operasi kognitif yang tinggi, mereka belajar membedakan interpretasi atau deskripsi sebab dan akibat. Sekolah menengah pertama adalah waktu yang tepat untuk pengajaran awal tentang keterampilan berpikir tingkat tinggi atau proses-proses berpikir kompleks. Hal ini disebabkan perkembangan kapasitas kognitif siswa remaja telah matang untuk diberikan tantangan berupa pemikiran yang lebih kompleks (Corebima, 1999).

Kemampuan berpikir berhubungan dengan prestasi belajar biologi dan keterampilan berpikir. Nordland dan De Vito menyatakan ada korelasi antara 
tingkat penalaran dengan hasil belajar IPA. Hasil belajar siswa meningkat secara signifikan setelah mereka dilatih dengan keterampilan berpikir tertentu (Suryani, 2009). Rendahnya keterampilan berpikir siswa dapat disebabkan karena strategi yang diterapkan guru dalam pembelajaran belum berorientasi pada pemberdayaan berpikir tingkat tinggi, dan hanya menekankan pada pemahaman konsep. Melalui KTSP 2006 telah ditetapkan bahwa salah satu standar kompetensi lulusan SMP adalah menunjukkan kemampuan berpikir tinggi. Oleh karena itu diharapkan kepada para guru agar dalam merencanakan dan melaksanakan pembelajaran yang mampu melatih dan mengembangkan keterampilan berpikir siswa di samping pemahaman konsep. Hal ini penting untuk dilakukan karena keterampilan berpikir tinggi merupakan suatu life skill bagi siswa untuk menghadapi tantangan kehidupan di abad ke 21 ini (Sanjaya, 2008).

Keterampilan berpikir kritis dapat diberdayakan melalui strategi pembelajaran tertentu, salah satu diantaranya adalah pembelajaran inkuiri sebagaimana dinyatakan oleh Corebima (2005), bahwa pembelajaran berbasis inkuiri berpotensi memberdayakan keterampilan berpikir karena pembelajaran inkuiri melatih indikator berpikir kritis, di antaranya 1) Merumuskan masalah, 2) Memberi argument, 3) Melakukan induksi: Melakukan investigasi atau pengumpulan data, membuat generalisasi dari data, membuat tabel dan grafik, membuat kesimpulan terkait hipotesis. Pembelajaran inkuiri bertujuan untuk mengembangkan tingkat berfikir dan juga keterampilan berfikir kritis (Corebima, 2005). Pada prinsipnya pengajaran inkuiri membantu siswa bagaimana merumuskan pertanyaan, mencari jawaban atau pemecahan untuk memuaskan keingintahuannya dan untuk membantu teori dan gagasannya tentang dunia. Lebih jauh lagi dikatakan bahwa pembelajaran inkuiri bertujuan untuk mengembangkan tingkat berpikir dan juga keterampilan berpikir kiritis. Dalam pembelajaran perlu ditetapkan strategi. Strategi pembelajaran adalah suatu kegiatan pembelajaran yang harus dikerjakan guru dan siswa agar tujuan pembelajaran dapat dicapai secara efektif dan efisien. Untuk melaksanakan strategi diperlukan seperangkat metode pengajaran. Ada berbagai metode yang 
dapat digunakan dalam pembelajaran, namun dalam penelitian ini digunakan metode tanya jawab dan metode kerja kelompok karena peneliti ingin membandingkan hasil belajar antara pembelajaran inkuiri secara individu dan pembelajaran inkuiri secara kelompok.

Berpijak pada teori dan bertolak dari pentingnya keterampilan berpikir itu untuk diupayakan dan diimplementasikan dalam pembelajaran serta pengaruhnya terhadap hasil belajar, maka perlu adanya penelitian yang mengkaji tentang "Perbandingan Hasil Belajar antara Pembelajaran Inkuiri Melalui Metode Tanya Jawab dan Kerja Kelompok”.

\section{METODE PENELITIAN}

\section{Jenis Penelitian}

Penelitian ini merupakan penelitian quasy eksperimen yang bertujuan untuk melihat perbedaan hasil belajar dua kelompok dengan treatment pembelajaran yang berbeda.

\section{Populasi dan Sampel}

Populasi dalam penelitian ini adalah semua siswa kelas VIII SMP Negerilima dalam wilayah Maluku Tengah. Sampel penelitian diambil 2 kelas untuk ujicoba yang ditentukan secara random pada kelas VIII dengan cara undian. Hasil undian diperoleh kelas kelas VIII C sebagai kelas kerja kelompok dengan jumlah sampel 25 orang dan kelas VIII A sebagai kelas tanya jawab dengan jumlah sampel 25 orang.

\section{Variabel Penelitian}

Variabel bebas dalam penelitian ini adalah pembelajaran inkuiri dengan metode tanya jawab dan metode kerja kelompok dengan indikator keterlaksanaan RPP. Variabel terikat dalam penelitian ini adalah hasil belajar dengan indikator nilai tes hasil belajar.

\section{Instrumen Penelitian}

1. Tes Hasil Belajar

Instrumen ini dilengkapi dengan kisi-kisi test dan butir test, yang disusun berdasarkan tujuan pembelajaran yang hendak dicapai dalam upaya untuk mengetahui tingkat pemahaman siswa pada materi yang telah diajarkan. soal test pada kelompok inkuiri metode kerja kelompok dan inkuiri metode tanya jawab adalah sama. Test terdiri dari pretest dan posttest yang dibuat sama untuk kelompok inkuiri kerja kelompok dan kelompok inkuiri tanya jawab. Soal pretest pararel dengan soal posttest sebanyak 15 butir soal dalam bentuk 15 soal pilihan ganda. 
Pretest diberikan sebelum pembelajaran dimulai dan posttest diberikan setelah pembelajaran.

2. Lembar observasi keterlaksanaan rencana pembelajaran (RPP)

Lembar observasi pengamatan digunakan untuk mengamati kemampuan guru mengelola pengajaran inkuiri dengan strategi tanya jawab dan tugas tugas kelompok.

\section{Teknik Pengumpulan Data}

1. Memberikan post-test pada kelas inkuiri tanya jawab dan kelas inkuiri kerja kelompok untuk mengetahui hasil belajar siswa setelah penerapan pembelajaran inkuiri untuk mendapatkan data post-test. Test dilakukan secara klasikal dikerjakan oleh setiap siswa. Post-test diberikan selesai pembelajaran.

2. Observasi (pengamatan) terhadap keterlaksanaan pembelajaran. Melakukan pengamatan terhadap keterlaksanaan skenario RPP. 2002): keterlaksanaan skenario RPP. 2002):

Pengamatan menggunakan lembar observasi pembelajaran dengan mengisi atau menuliskan hasil pengamatannya pada lembar observasi pada saat proses pembelajaran berlangsung, yang dilakukan oleh teman sejawat untuk tiap metode pembelajaran.

\section{Tehnik Analisa Data}

Analisis data untuk melihat pengaruh antara pembelajaran inkuiri metode tanya jawab dan metode kerja kelompok terhadap hasil belajar siswa. Dianalisis dengan menggunakan rumus product moment:

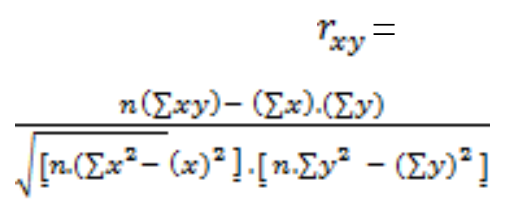

Selanjutnya untuk menyatakan besar kecilnya hubungan metode tanya jawab dan metode kerja kelompok terhadap hasil belajar ditentukan dengan rumus koefisien diterminan (Sudjana,

$$
\begin{aligned}
\mathrm{KP}=\mathrm{r}^{2} \times 100 \% \quad \text { dimana: } \mathrm{KP} & =\text { nilai koefisien deteminan } \\
\mathrm{r} & =\text { nilai koefisien korelasi }
\end{aligned}
$$

Untuk melihat seberapa besar pengaruh pembelajaran inkuiri metode tanya jawab dan metode kerja kelompok terhadap hasil belajar siswa, maka diuji dengan menggunakan rumus uji t: 


$$
t_{\text {hitung }}=\frac{r \sqrt{n-2}}{\sqrt{1-r^{2}}}
$$

\section{HASIL PENELITIAN}

\section{Hasil Keterlaksanaan Pembelajaran}

Tabel 1 Hasil Pengamatan Pembelajaran Inquiri Metode Tanya Jawab dan Kerja Kelompok

\begin{tabular}{|c|l|c|c|c|}
\multirow{2}{*}{ No } & \multirow{2}{*}{ Aspek yang Diamati } & \multicolumn{2}{|c|}{ Rata-rata Penilaian } & \multirow{2}{*}{ Kategori } \\
\cline { 3 - 5 } & & Tanya Jawab & Kerja Kelompok & \\
\hline 1 & Pendahuluan & 3,16 & 3.08 & Baik \\
\hline 2 & Kegiatan inti & 3,08 & 3,13 & Baik \\
\hline 3 & Penutup & 3,25 & 3,25 & Baik \\
\hline 4 & Pengelolaan waktu & 3 & 3 & Baik \\
\hline 5 & Suasana kelas & 3,15 & 3,15 & Baik \\
\hline
\end{tabular}

Berdasarkan hasil pengamatan berbentuk pilihan ganda. Tes ini pada Tabel 1 menunjukan skor rata - rata digunakan untuk mengetahui keberhasilan aspek yang diamati untuk tiap-tiap proses pembelajaran. Keberhasilan kegiatan. Pengamatan meliputi pembelajaran diukur dengan pencapaian pendahuluan, kegiatan inti, penutup, hasil belajar berdasarkan standar kiteria pengelolaan kelas, dan suasanan kelas ketuntasan minimal (KKM) SMP mendapatkan penilaian rata-rata dengan Negerilima Leihitu, apabila proporsi kategori baik. Hal ini menunjukkan bahwa jawaban yang dijawab benar tiap siswa rencana pembelajaran telah dilaksanakan adalah 65 , maka pembelajaran dikatakan dengan baik, baik menggunakan metode tuntas, apabila $70 \%$ dari seluruh siswa dan tanya jawab maupun dengan metode kerja mencapai proporsi KKM 65 dikatakan kelompok.

\section{Hasil Tes Belajar} tuntas secara klasikal. Hasil belajar siswa

Hasil belajar diukur dengan menggunakan soal tes hasil belajar 
Tabel 2 Ketuntasan Hasil Belajar Metode tanya Jawab dan Metode Kerja Kelompok

\begin{tabular}{|c|c|c|c|c|c|c|c|c|}
\hline \multirow{2}{*}{ Tes Belajar } & \multicolumn{4}{|c|}{ Metode Tanya Jawab } & \multicolumn{3}{c|}{ Metode Kerja kelompok } \\
\cline { 2 - 9 } & \multicolumn{2}{|c|}{ Frekuensi } & \multicolumn{2}{c|}{ Persentase (\%) } & \multicolumn{2}{c|}{ Frekuensi } & \multicolumn{2}{c|}{ Persentase (\%) } \\
\cline { 2 - 9 } & Tuntas & $\begin{array}{l}\text { Tidak } \\
\text { Tuntas }\end{array}$ & Tuntas & $\begin{array}{l}\text { Tidak } \\
\text { Tuntas }\end{array}$ & Tuntas & $\begin{array}{l}\text { Tidak } \\
\text { Tuntas }\end{array}$ & Tuntas & $\begin{array}{l}\text { Tidak } \\
\text { Tuntas }\end{array}$ \\
\hline Pretes & 1 & 24 & $4 \%$ & $96 \%$ & 0 & 25 & $0 \%$ & $100 \%$ \\
\hline Postes & 21 & 4 & $84 \%$ & $16 \%$ & 23 & 2 & $92 \%$ & $8 \%$ \\
\hline
\end{tabular}

Dari Tabel 2 menunjukan bahwa

ketuntasan pretes kelas metode tanya tujuannya adalah untuk mengetahui jawab hanya $1(4 \%)$ siswa yang tuntas dan seberapa pengaruh pembelajaran inkuiri $24(96 \%)$ siswa tidak tuntas. Pada kelas metode kerja kelompok ketuntasan pretes metode tanya jawab dan metode kerja kelompok terhadap hasil belajar siswa. Dalam penelitian ini taraf signifikansi semus siswa tidak tuntas. Setelah yang digunakan ialah sebesar 5\% atau dilaksanakan pembelajaran, ketuntasan 0,05 .

postes dari kelas metode tanya jawab hanya $4(16 \%)$ orang siswa yang tidak tuntas dan $21(84 \%)$ orang siswa tuntas. sementara pada kelas metode kerja kelompok $2(8 \%)$ orang tidak tuntas .dan $23(92 \%)$ orang siswa tuntas. Secara individu dikatakan tuntas karena proporsi diatas 65, tuntas secara klasikal karena $84 \%$ dari kelas metode tanya jawab siswa mencapai proporsi di atas 65. Dan pada kelas metode kerja kelompok tuntas secara klasikal karena $92 \%$ dari seluruh siswa mencapai proporsi diatas 65 .

\section{Hasil Uji t}

Untuk mengetahui ada tidaknya pengaruh pembelajaran metode tanya jawab dan metode kerja kelompok dilakukan dengan menggunakan uji t, 


\section{PEMBAHASAN}

Hasil pengamatan keterlaksanaan RPP, menunjukkan bahwa guru dapat melaksanakan pembelajaran inkuiri dengan baik, baik metode tanya jawab maupun metode kerja kelompok. Seluruh aspek dalam RPP terlaksana dengan baik. Hal ini ditunjukkan dengan skor pengamatan yang diberikan oleh pengamat dengan kategori baik. Rencana Pelaksanaan Pembelajaran (RPP) yang dikembangkan adalah RPP yang dikembangkan berorientasi pada pembelajaran inkuiri, dengan menggunakan metode tanya jawab dan metode kerja kelompok. Disamping berorientasi pada pembelajaran inkuiri dengan metode tanya jawab dan metode kerja kelompok, juga untuk meningkatkan kompetensi siswa dalam kegiatan pembelajaran biologi, yang terlihat dari: (1) tujuan pembelajaran, (2) komponen Kegiatan Belajar Mengajar (KBM) yang tertulis pada RPP, dan (3) komponen evaluasi hasil belajar yang tercantum dalam RPP.

Ketuntasan belajar klasikal pada kelas pembelajaran inkuiri metode tanya jawab mencapai $84 \%$ dan Keadaan ini membuktikan bahwa pembelajaran inkuiri selain berpotensi memberdayakan keterampilan berfikir kritis sesuai dengan pendapat: 1) melalui pendekatan inkuiri siswa dikondisikan untuk berfikir secara kritis dan kreatif, 2) bahwa pembelajaran inkuiri berpotensi memberdayakan keterampilan berfikir kritis, 3) yang menyatakan pembelajaran inkuiri melatih indikator berfikir kritis seperti merumuskan masalah, memberi argument, melakukan induksi dan 4) penelitian yang diungkapkan menyimpulkan pembelajaran dengan inkuiri terbimbing memiliki dampak positif dalam mengembangkan berfikir kritis siswa yang berkaitan dengan pengembangan inteligensi siswa (Nur, 2002). Pembelajaran inkuiri juga mampu meningkat hasil belajar dalam hal ini ketuntasan belajar oleh Suryani (2009), bahwa dengan inkuiri terbimbing dapat meningkatkan prestasi belajar siswa yang ditandai dengan ketuntasan belajar siswa.

Demikian pula dengan kelas pembelajaran inkuiri metode kerja kelompok, ketuntasan hanya mencapai 92\% dan mancapai peningkatan menjadi 100\%.Keadaan ini menunjukkan bahwa pembelajaran inkuiri berpotensi memberdayakan dan meningkatkan kemampuan berfikir kritis sebagaimana 
yang diungkapkan oleh bahwa penerapan inkuiri dengan strategi kooperatif akan dapat meningkatkan kemampuan berfikir kritis sehingga memberi dampak pada peningkatan hasil belajar dalam hal ini ketuntasan belajar sebagaimana yang pernah diteliti oleh Winarni (2001), menemukan bahwa pembelajaran dengan pendekatan inkuiri, meningkatkan hasil belajar kognitif.

Hasil belajar antara siswa yang diajarkan dengan pembelajaran inkuiri metode tanya jawab dan metode kerja kelompok menunjukkan tidak ada perbedaan yang signifikan. Berdasarkan hasil hasil uji $t$ dimana $t_{\text {hitung }}$ sebesar 0,56 lebih kecil dari tabel 2,069 yang berarti tidak ada pengaruh yang signifikan pada hasil belajar antara metode tanya jawab dan kerja kelompok terhadapahasil belajar siswa. Tidak adanya pengaruh yang signifikan ini disebabkan dua kelas yang diberi perlakuan merupakan sampel yang setara dan sama

\section{KESIMPULAN}

Berdasarkan hasil penelitian dan pembahasan, dapat disimpulkan bahwa tidak ada perbedaan hasil belajar antara siswa yang diajarkan pembelajaran inkuiri metode tanya jawab dan metode kerja kelompok.

\section{SARAN}

1. Pembelajaran inkuiri hendaknya dibudayakan pada siswa karena strategi pembelajaran ini efektif untuk melatih keterampilan berfikir tingkat tinggi sehingga siswa menjadi terlatih untuk berfikir kritis dan ini sangat baik untuk perkembangan penalaran dan intelektual siswa.

2. Pada metode kerja kelompok guru hendaknya lebih memperhatikan siswa saat bekerja dalam kelompok. ntuk melaksanakan pembelajaran inkuiri waktu pembelajaran sebaiknya lebih dari 2 x 40 menit karena pembelajaran inkuiri membutuh waktu yang panjang.

\section{DAFTAR PUSTAKA}

Amien, M. 1986. Metode Discovery Inquiry dalam Pendidikan IPA. Depdikbud, Dirjen Dikti. Jakarta.

Amin, M. 1987. Mengajarkan IPA dengan Menggunakan Metode DiscoveryInquiry. Depdikbud, Dikti Projek Pengembangan LPTK. Jakarta.

BSNP. 2006a. Panduan Penyusunan Kurikulum Tingkat Satuan Pendidikan Jenjang Pendidikan Dasar dan Menengah. Departemen Pendidikan Nasional. Jakarta.

BSNP. 2006b. Kurikulum Tingkat Satuan 
Pendidikan.

Departemen

Pendidikan Nasional. Jakarta.

Corebima, A.D. 1999. Proses dan Hasil

Pembelajaran MIPA di SD, SLTP,

dan SMU: Perkembangan

Penalaran Siswa Tidak Dikelola

Secara Terencana Proceeding

Seminar Quality Improvement of

Mathematics and Science

Education in Indinesia (JICA).

Bandung, Agust 11.

Corebima, A.D. 2005. Pemberdayaan

Berpikir Siswa pada Pembelajaran

Biologi: Satu Penggalakan

Penelitian Payung di Jurusan

Biologi UNM. Makalah

Disampaikan dalam Seminar

Nasional Biologi dan

Pembelajaran FMIPA UNM,

Malang: 3 Desember 2005.Joni,

T.R. 1992. Memicu Perbaikan

Pendidikan melalui Kurikulum.

Jurnal Ilmu Pendidikan.

Kardi, S. dan Nur, M. 2000. Pengantar pada Pengajaran dan Pengelolaan Kelas. UNESA University Press. Surabaya

Karyadi, B. dan Winarni, E. 2000. Pelaksanaan Pembelajaran Biologi dengan Pendekatan Inkuiri dalam Upaya Meningkatkan Ketuntasan Belajar Siswa SLPT 11 Bengkulu. Laporan Penelitian Bengkulu. Bengkulu: LPPM Universitas Bengkulu.

Nurhayati Nunung. 2006.Pelajaran IPA Biologi. Yrama Widya. Bandung.

Nur, M. dan Wikandari, P.R. 1998. Pendekatan-Pendekatan

Konstruktivisme dalam Pembelajaran. IKIP Surabaya.

Nur, M dan Wikandari, P.R. 1998. Pengajaran Berpusat pada Siswa dan Pendekatan Konstruktivisme dalam Pengajaran. IKIP Surabaya.

Nur, M. 1999. The Developing of Science Instruktional Model Using Process Approach to Increase Student, Reasoning and Thinking Ability. Dikti. Surabaya

Nur, M. 2002. KeterampilanKeterampilan Proses Sains. Surabaya: Pusat Sains dan Matematika Sekolah UNESA.

Oates, K, K. 2002. Inquiry Science: Case Study in Antibiotic Prospecting. The American Biology Teacher, 64(3): 184-187.

Sanjaya, W. 2008. Perencanaan dan Desain Sistem Pembelajaran. Kencana Prenada Media Group. Jakarta

Subiyanto. 1988. Pendidikan Ilmu Pengetahuan Alam. Depdikbud, Dirjen Dikti, Proyek Pengembangan Lembaga Pendidikan Tenaga Kependidikan. Jakarta

Sudjana, N. 2002. Dasar-Dasar Proses Belajar Mengajar. Sinar Baru. Bandung

Sudjana, N. 1996. Metoda Statistik. Tarsito. Bandung

Suryani, N. D. 2009. Pengembangan Keterampilan Berfikir Kritis Siswa pada Pembelajaran Fisika Materi Pokok Kalor Melalui Model Pembelajaran Inkuiri Terbimbing. Jurnal Pendidikan Delta Widya. Dinas Pendidikan. Surabaya

Usman, U.M. 1994. Menjadi Guru Profesional. PT. Gramedia. Bandung.

Zamroni. 2000. Paradigma Pendidikan Masa Depan. Bigraf Publishing. Yogyakarta. 